\title{
A Rare Case of Arteriovenous Hemangioma Clinically Mimicking Pigmented Nevus
}

\author{
Sri Lestari ${ }^{1}$, Tofrizal $^{2}$, Yenny Raflis ${ }^{1}$
}

\begin{abstract}
Abstrak
Arteriovenous hemangioma ( $\mathrm{AH}$ ) adalah lesi jinak pembuluh darah kulit yang jarang, biasanya muncul pada kulit wajah berupa lesi tunggal, meninggi, papul merah, atau keunguan; kadang-kadang papul coklat. Dilaporkan satu kasus $\mathrm{AH}$ dengan gambaran klinis menyerupai nevus pada pasien perempuan yang berusia 19 tahun. Ini adalah kasus pertama di Bagian IImu Kesehatan Kulit dan Kelamin RS. Dr. M. Djamil Padang. Pasien datang dengan keluhan bintik hitam di lengan kanan bawah sejak satu bulan lalu. Pada pemeriksaan fisik, terdapat papul hitam soliter, dengan ukuran 0,3 $\times 0,4 \mathrm{~mm}$, bentuk bulat, skuama halus, berbatas tegas, pinggir reguler dengan permukaan tidak rata. Berdasarkan pemeriksaan histopatologi, lesi terdiri dari pembuluh darah yang berdinding tebal dan berdinding tipis yang sangat melebar, penuh dengan eritrosit dan dilapisi oleh selapis endotel yang sesuai untuk $\mathrm{AH}$. Arteriovenous hemangioma adalah tumor yang dijumpai pada usia pertengahan hingga dewasa lanjut dengan puncak insiden pada dekade keempat dan kelima kehidupan. Pada kasus ini, umur pasien tergolong dewasa muda dengan gambaran klinis lesi menyerupai nevus pigmentosus.
\end{abstract}

Kata kunci: arteriovenous hemangioma, kasus jarang, nevus pigmentosus

\begin{abstract}
Arteriovenous hemangioma $(A H)$ is a rare benign vascular skin lesion, which typically appears in the skin of the face and extremities and most commonly occurring on the head and neck region with appearances as single, raised, red, or violaceous papules; sometime tan papule. A case of AH clinically mimicking pigmented nevus in 19year-old woman was reported. This is the first case in Dermatology Department of Dr. M. Djamil Padang Hospital. She complained about a black pimple on the right lower arm since one month. Physical examination: there is a solitare black papule, with 0,3×0,4 mm, round shape, fine scales, well defined, regular border with irreguler surface. Histopathology findings: the lesions consist of thicked-walled and very dilated thin-walled vessels that full-filled with erythrocytes and are lined by an endothelial layer that suitable for AH. Arteriovenous hemangioma is a tumor of middle-age to elderly adults with a peak incidence in the fourth and fifth decades of life. In this case, the patient was young adult and clinically the lesion mimicking pigmented nevus.
\end{abstract}

Keywords: arteriovenous hemangioma, rare case, pigmented nevus

Affiliasi penulis : 1. Bagian Kulit dan kelamin Fakultas Kedokteran Universitas Andalas, 2. Bagian Patologi Anatomi Fakultas Kedokteran Universitas Andalas

Korespondensi : Yenny Raflis, email: yennyraflis@gmail.com, Telp: 085374633602

\section{INTRODUCTION}

Arteriovenous hemangioma $(\mathrm{AH})$, also known as cirsoid aneurysm or acral arteriovenous tumor, represents a benign vascular skin lesion, which typically appears in the skin of the face and extremities. ${ }^{1,2}$ It is a tumor of middle-age to elderly adults with a peak incidence in the fourth and fifth decades of life. Biberstein and Jessner reported the first case of $\mathrm{AH}$ in 1956 as "cirsoid aneurysm". The entity then lay relatively dormant in the literature until 1974 when Girard et al. characterized the salient clinical and histologically similar lesions that they termed arteriovenous hemangioma. Subsequent 
reports by Carapeto et al. and Connely and Winkelmann have confirmed the benign nature of these vascular tumors and have emphasized the acral pattern of distribution by the assignment of the name acral arteriovenous tumor. ${ }^{1,2}$

Arteriovenous hemangioma maybe

cutaneous or mucosal. These lesions grow slowly and achieve only a small size with range from $1 \mathrm{~mm}$ to 3 $\mathrm{cm}$, with an average of 4 to $6 \mathrm{~mm}$ in months to many years. Most are asymptomatic, but a minority of patient complain enlargement, pain, or pruritus. ${ }^{1}$ The lesions most commonly present as single, raised, red, or violaceous papules; sometime tan papule on the head or neck. Microscopically, $\mathrm{AH}$ lesions are wellcircumscribed but uncapsulated. They are composed of an intimate admixture of thick-walled and thin-walled blood vessels distributed within the superficial and middle dermis. ${ }^{1}$ Muscular walled vessels in haphazard cluster in the dermis. More vessels have features of veins than of arteries (and lack internal elastic lamina with an elastic stain). ${ }^{3}$

Enzinger and Weiss divide arteriovenous hemangioma into two types, "deep" and "superficial". The so-called "deep" type, is asscociated with varying degrees of shunting, and is regarded as a malformation. It is generally affect young adult and adolescent. Although called "deep", lesions can occur close to the skin and they may pulsate or writhe due to afferent arterial blood flow if large shunts are present. These lesions are referred as cirsoid or arteriovenous aneurysms. The superficial form includes lesions classified as arteriovenous haemangioma or acral arteriovenous tumor by Capareto et al. and generally affected middle age to elderly adult. ${ }^{2.4}$

The pathologic nature and etiology of Ahs remain a matter of speculation, and both congenital and acquired Ahs have been reported. ${ }^{5}$ However, hamartomatous proliferation either of the subpapilary vascular plexus or of the Sucquet-Hoyer canal of the true glomous is proposed as a possible histogenetic mechanism. Treatment of choice is complete surgical excision. ${ }^{6}$

\section{CASE REPORT}

A 19-year-old woman came to Dermato-Venereology out-patient Department of Dr. M. Djamil Hospital on December $28^{\text {th }} 2011$ with chief complaint there was a black pimple on the right lower arm since one month ago. Initially, about 2 years ago, there was a tiny reddish pimple arised on her right lower arm. The size of the pimple only as pinhead size. The pimple was painless, sometimes itchy, not easy to bleed although she scratched it, and not become large since appeared. In last two months, she often touched the pimple and scratched it because itchy. Since one month ago, she felt the pimple become larger and easily bleed after she scratched it and the color turned into black. On physical examination we found a solitare black papule, with $0,3 \times 0,4 \mathrm{~mm}$ in diameter, round shape, fine scales, the regular border with irreguler surface. Then, we diagnosed this patient with pigmented naevus at the beginning with differential diagnosis pigmented basal cell carcinoma $\left(T_{1} N_{0} M_{0}\right)$ and pyogenic granuloma. To exclude those differential diagnosis, we did histopathology examination by skin biopsy and the result showed mild acanthosis dan hyperkeratosis on epidermis and superficial dermis containing thicked-walled and very dilated thin-walled vessels that full-filled with erythrocytes and are lined by an endothelial layer. There are also seen bleeding area and mild lymphocytes perivasculer. This features supported to $\mathrm{AH}$.

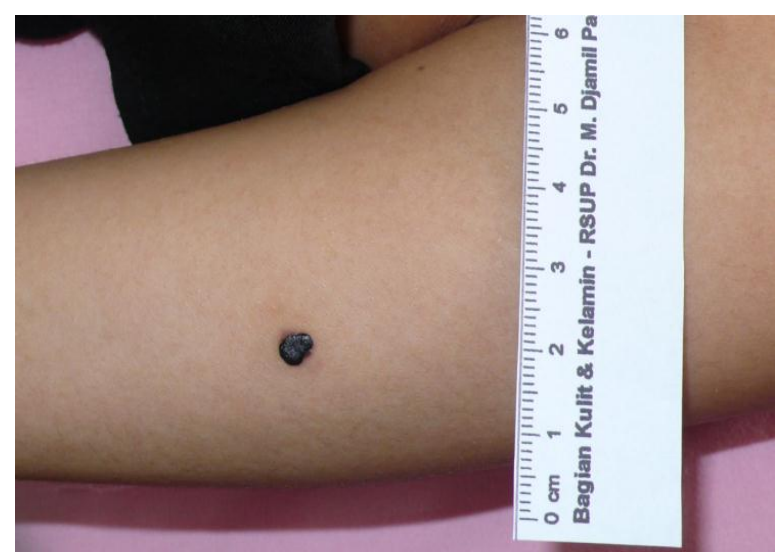

Figure 1. Black pimple on the right lower arm 


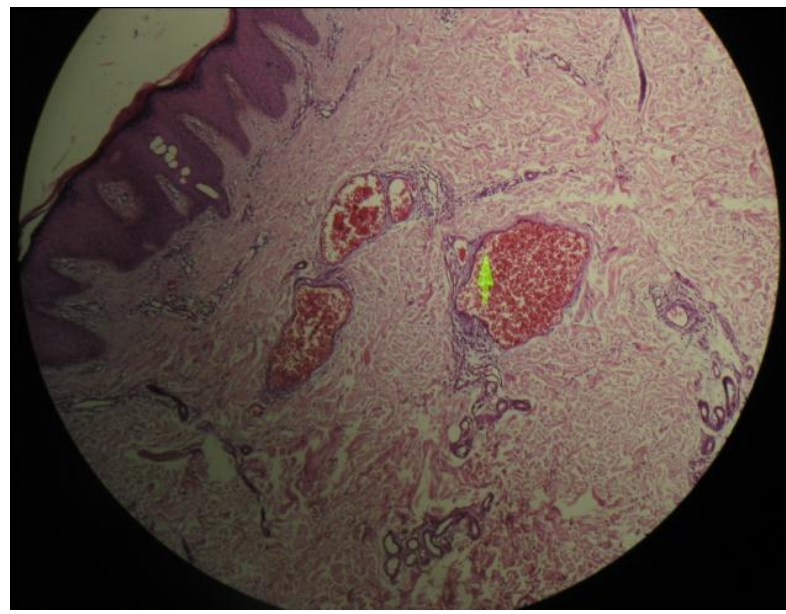

Figure 2. Histopathology examination: showed thickedwalled and very dilated thin-walled vessels that full-filled with erythrocytes and are lined by an endothelial layer (yellow arrow)

\section{DISCUSSION}

Arteriovenous hemangioma $(\mathrm{AH})$ is a rare vascular anomaly, with the principal histologic feature of which is a collection of thick-walled and thin-walled blood vessels with the structural characteristics of both arteries and veins. The exact incidence of $\mathrm{AH}$ is unknown. In most series, males are predominant. ${ }^{2,4}$

We reported a case of superficia arteriovenous hemangioma in 19-year-old woman. The problems in this case are: a rare case and diagnosis. There are two form of $\mathrm{AHs}$ according to Enzinger and Weiss, superficial and deep $\mathrm{AH}$. Despite benign histology, deep lesions may produce serious systemic signs and symptoms such heart failure and Kasabach Merritt syndrome, because of extensive arteriovenous shunting and soft tissue hypertrophy. Diagnosis is usually made in conjunction with clinical, arteriographic, and radiographic investigations. By contrast, superficial $\mathrm{AHs}$ do not have systemic implications, but may nevertheless prove troublesome because of their tendency to affect the skin of the face, particularly the lips and perioral area. Symptoms are mild and include pain and intermittent bleeding. ${ }^{2,4}$

In this case, the patient was a young lady, and she did not have any systemic signs and symptoms. Mostly symptoms that she complained in last one month were enlargement and discoloration of the lesion, pruritus and intermitten bleeding.

Initially, we diagnosed this patient as pigmented nevus (common acquired nevomelanocytic nevus) because at the first time the patient came into hospital, the lesion was a small blackish papule that mimicking nevus. Pigmented nevus or acquired nevi primarily develop during childhood and early adulthood. Common acquired nevi vary considerably in their gross appearance. In general, appearance to the naked eye is orderly: the lesions have a homogeneous surface and coloration pattern, round or oval shape, regular outlines, and relatively sharp borders. Common acquired nevi may be papillomatous, dome-shaped, pedunculated, or flattopped and usually are flesh-colored, pink, or brown. Very dark brown and black are unusual colors for common acquired nevi in lightly pigmented people. In contrast, dark pigmentation is usual for common acquired nevi in people who have darkly pigmented skin. The surfaces of nevi may reveal hair that is less than, equal to, or greater than that of surrounding skin. Based on histopathology features, nevomelanocytes in the epidermis have a nuclear size similar to or larger than nuclei of epidermal melanocytes. Nevomelanocytes are arranged in nests surrounded by a smooth perimeter of epidermis and separated from nevomelanocytes by a retraction artifact. ${ }^{7}$

The second possibility was pigmented basal cell carcinoma (BCC). From anamnesis there was reddish papule in right lower arm that turned into black in color (hyperpigmented) and become larger in last one month. The lesion also easily bleeding when the patient scratch it. Pigmented BCC is sub-type nodular BCC that exhibits increased melanization. Pigmented BCC shows histologic features similar to those of nodular BCC (characterized by nodules of large basophilic cells and stromal retraction ) but with the addition of melanin. Approximately $75 \%$ of BCCs contain melanocytes, but only $25 \%$ contain large amounts of melanin. The melanocytes are interspersed between tumor cells and contain numerous melanin granules in their cytoplasm and dendrites. Although the tumor cells contain little melanin, numerous melanophages populate the stroma surrounding the tumor. ${ }^{8}$

The third possibility was pyogenic granuloma (PG), also known by its correct histopathologic description lobular capillary hemangioma. It is one of the most common vascular tumors of infants, children, and can also occur in adults, particularly in young 
adults and also pregnant women. Pyogenic granuloma usually presents as a solitary, red, rapidly growing papule or nodule, often with a subtle collarette of scale. Typical locations include the cheek or forehead but virtually any body site may be affected. They often develop an eroded surface, with subsequent bleeding which can be profuse, resulting in the moniker the band-aid disease. The lesion of PG does not involute spontaneously, but simple curettage with electrocautery is usually curative. Microscopically, this is an exophytic, often ulcerated lesion characterized by lobulated proliferation of capillary sized vessels in a loose and oedematous stroma. The surface epithelium is attenuated and at the margin an epidermal collarette is formed by elongated rete ridges. ${ }^{9}$ Clinically, the lesion of this patient can mimick PG as papule with fine scales and easily bleed.

The definite diagnosis in this patient was superficial $\mathrm{AH}$. This diagnosis was made based on histopathology examination. There are some differential diagnosis in this case, but all of that can exclude by histopathology finding. The lesion was started as a single tiny reddish pimple arised on her right lower arm since two years ago. The lesion asymptomatic, grow slowly and achieve only a small size. We did biopsy excision and the result of histopathology examination was the lesions consist of thicked-walled and very dilated thin-walled vessels that full-filled with erythrocytes and are lined by an endothelial layer that suitable for $\mathrm{AH}$.

Since the first case report in 1956, 4 series studies documenting $69,15,47$, and 6 cases have demonstrated the clinicopathologic features of $\mathrm{AH}$. Beside face and neck region, the skin of the limbs is the next most commonly affected location. Regardless of anatomic site, affected patients have a wide age range, with the fifth and sixth decades most commonly affected. ${ }^{5}$

Barret Aw et al. (London, 2000) reported that from 470 vascular lesions between 1952 and 2000, 36 lesions $(7,7 \%)$ from 35 patients had the features of superficial $\mathrm{AH}$. All were situated intraorally or on the lip vermillion. $^{5}$ Akiyama $M$ et al. (Japan,2001) also reported 4 cases of $\mathrm{AH}$ in chronic liver disease. All patients showed an asymptomatic solitary domeshaped reddish papule, $5 \pm 10 \mathrm{~mm}$ in diameter, on the face (first, second and third patients) or chest (fourth patient). Histopathological examination of the tumours revealed features of $\mathrm{AH}$, namely a well-circumscribed lesion composed of vascular structures of various sizes reminiscent of arteries and veins. ${ }^{2}$

The origin, cause, and nomenclature of $\mathrm{AH}$ have been debated at length, confusion often centering around the terms hemangioma and vascular malformation. Some authorities stipulate that hemangiomas occur during the first month of life and proliferate rapidly to a plateau, after which they stabilize and gradually involute. Endothelial or mast cell hyperplasia can be prominent. By contrast, vascular malformations are present at birth, grow in proportion to somatic growth, and never regress spontaneously. The blood vessels are abnormal arteries, veins, capillaries, or lymphatics and rarely show endothelial or mast cell hyperplasia. Based on these criteria, however, superficial $\mathrm{AH}$ may have the features of both entities. ${ }^{5}$

There was no case of superficial $\mathrm{AH}$ with lesion clinically mimicking pigmented nevus has been reported. This is the first case of $\mathrm{AH}$ in our department. In this case, we did biopsy excision with concideration that the lesion was small, occurring of discoloration and bleeding of the lesion that tend to be a carcinoma and to exclude the differential diagnosis. The choice of treatment of $\mathrm{AH}$ is surgical exicision, and recurrences have never been reported. The prognosis this lesion was bonam. ${ }^{6}$

\section{REFERENCES:}

1. Cruz DJS, Singh A. Vascular tumors of the skin. In: Nouri K, editors. Skin cancer. New York: McGraw Hill. 2008: 293-4.

2. Akiyama $M$, Inamoto $M$. Arteriovenous haemangioma in chronic liver disease: clinical and histopathological features of four cases. British Journal of Dermatology. 2001; 144: 604-9.

3. Montalli VAM, Martinez EF, Thomaz LA, Furuse C, Araujo VC. Oral arteriovenous hemangioma in patient with hepatitis C. Journal of Cutaneous 
Pathology. 2011: 1-3.

4. Leboit PE. Vascular proliferations. In: Grant-kels JM, editors. Color atlas of dermatopathology. New York: Informa Healthcare USA, Inc; 2007: 319-325.

5. Barret AW, Speight PM. Superficial arteriovenous hemangioma of the oral cavity. Oral Surg Oral Med Oral Pathol Oral Radiol Oral Endod. 2000; 90; 731 8.

6. Koutlas IG, Jessurun J. Arteriovenous hemangioma: a clinicopathological and immunohistochemical study. J Cutan Pathol. 1994: 343-9.

7. Grichnick JM, Rhodes AR, Sober AJ. Benign neoplasias and hyperplasias of melanocyte. In: Wolff K, Goldsmith LA, Katz SI, Gilchrest BA,
Paller AS, Leffel DJ, eds. Fitzpatrick's dermatology in general medicine. $7^{\text {th }}$ ed. Vol 1. New York; Mc Graw Hill, Medical Publishing Division. 2008: 11049.

8. Carucci JA, Leffell DJ. Basal cell carcinoma. In: Wolff K, Goldsmith LA, Katz SI, Gilchrest BA, Paller AS, Leffel DJ, eds. Fitzpatrick's dermatology in general medicine. $7^{\text {th }}$ ed. Vol 1. New York; Mc Graw Hill, Medical Publishing Division. 2008: 103642.

9. Miller T, Frieden IJ. Vascular tumors. In: Wolff K, Goldsmith LA, Katz SI, Gilchrest BA, Paller AS, Leffel DJ, eds. Fitzpatrick's dermatology in general medicine. $7^{\text {th }}$ ed. Vol 1. New York; Mc Graw Hill, Medical Publishing Division. 2008: 1099-1109. 